\title{
Rancang Bangun Web Server Penampil Data Cuaca Berbasis Arduino Menggunakan Sensor BME280 dan BH1750FVI dengan Tiga Mode Tampilan Data
}

\author{
Arief Hendra Saptadi, Aris Kiswanto \\ Teknik Elektro, Fakultas Teknik, Universitas Muhammadiyah Semarang \\ Kampus 4. Jl. Kasipah No. 12 Candisari Semarang \\ E-mail: ariefhendras@unimus.ac.id
}

\begin{abstract}
ABSTRAK
Abstrak - Cuaca merupakan salah satu faktor yang memengaruhi aktivitas manusia. Oleh karenanya informasi mengenai kondisi cuaca yang akurat menjadi hal penting dan umumnya itu dapat diperoleh dari situs-situs di internet. Namun demikian, informasi tersebut lazimnya berkenaan dengan suatu wilayah dengan cakupan yang luas dan tidak memaparkan iklim mikro di lingkup lokal. Tujuan dari penelitian ini adalah melakukan rancang bangun suatu sistem penampil data cuaca berbasis Arduino Uno R3 untuk menayangkan data iklim di cakupan lokal dengan tiga mode tampilan data. Sistem ini menggunakan sensor BME280 untuk mengukur suhu $\left({ }^{\circ} \mathrm{C}\right)$, kelembaban relatif $(\%)$, tekanan udara (hPa) dan ketinggian $(\mathrm{m})$ dan sensor BH1750FVI untuk mengukur intensitas cahaya (lx). Waktu dan tanggal terjadinya pengukuran ditandai oleh RTC DS3231. Semua piranti tersebut menggunakan antarmuka $\mathrm{I}^{2} \mathrm{C}$ bertegangan kerja 3,3 V, yang bertindak sebagai slave dengan alamat perangkat yang berbeda-beda. Dari hasil pengukuran didapatkan bahwa nilai rerata suhu dan kelembaban, masing-masing adalah $28,72^{\circ} \mathrm{C}$ dan $65 \%$ dengan error $7,42 \%$ dan $10,95 \%$ yang mengindikasikan adanya bias antara hasil ukur di lingkup mikro dengan nilai pembanding dari situs cuaca yang mengacu ke wilayah yang lebih luas. Tekanan udara dan ketinggian menunjukkan nilai konstan dengan rerata masing-masing, 1011,2 hPa dan 240,35 m beserta error yang lebih kecil yaitu $0,2 \%$ dan $3,86 \%$. Intensitas cahaya berada pada rentang 58,05 - 100,63 lx dengan nilai rerata 83,85 lx. Data cuaca sudah dapat ditampilkan dengan baik melalui web server, komputer dan LCD alfanumerik. Informasi mengenai waktu dan tanggal pengukuran sudah dapat dimunculkan pada tiap mode tampilan yang mengindikasikan bahwa cip RTC telah bekerja sesuai perencanaan.
\end{abstract}

Kata kunci: Web Server, Cuaca, Data, BME280, BH1750FVI.

\begin{abstract}
Abstract - Weather is one of the factors that influence human activity. Therefore information about accurate weather conditions is important and generally it can be obtained from sites on the internet. However, this information usually relates to an area with a wide coverage and does not reveal the microclimate in the local scope. The purpose of this research is to design a weather data display system based on Arduino Uno R3 to display climate data in local coverage with three data display modes. This system uses the BME280 sensor to measure temperature ( $\square$ C), relative humidity (\%), air pressure (hPa) and altitude $(\mathrm{m})$ and the BH1750FVI sensor to measure light intensity (lx). The time and date when the measurement occurred is indicated by the RTC DS3231. All of these devices use an I2C interface with a working voltage of $3.3 \mathrm{~V}$, which acts as a slave with different device addresses. From the measurement results, it was found that the mean values of temperature and humidity were $28.72 \mathrm{C}$ and $65 \%$ respectively with an error of $7.42 \%$ and $10.95 \%$ which indicates a bias between the measurement results in the micro scope and the comparison value from the weather site. which refers to a wider area. Air pressure and altitude show constant values with mean, respectively, $1011.2 \mathrm{hPa}$ and $240.35 \mathrm{~m}$ along with smaller errors, namely $0.2 \%$ and $3.86 \%$. Light intensity is in the range $58.05-100.63 \mathrm{~lx}$ with a mean value of $83.85 \mathrm{~lx}$. Weather data can be displayed properly via a web server, computer and alphanumeric LCD. Information about the measurement date and time can be displayed in each display mode indicating that the RTC chip has worked as planned.
\end{abstract}

Keywords: Web Server, Weather, Data, BME280, BH1750FVI.

Copyright @ 2020 Universitas Muhammadiyah Jember. 


\section{PENDAHULUAN}

Kondisi cuaca memiliki banyak pengaruh terhadap aktivitas yang dilakukan oleh manusia. Beberapa pekerjaan seperti pada bidang pertanian, perikanan, transportasi hingga proyek pekerjaan umum memperhitungkan cuaca sebagai salah satu faktor yang berpengaruh dalam pelaksanaannya. Tentunya informasi mengenai cuaca yang akurat di lokasi tempat pekerjaan tersebut dilakukan menjadi suatu hal yang penting untuk didapatkan.

Saat ini informasi mengenai cuaca tersebut dapat diakses secara mudah melalui web, antara lain Weather Underground (https://www.wunderground.com/), World Weather Information Service (https://worldweather.wmo.int/en/home.html), Accuweather (https://www.accuweather.com/) hingga Weather Forecast dari Badan Meteorologi, Klimatologi dan Geofisika atau BMKG (https://www.bmkg.go.id/cuaca/prakiraan-cuaca-indonesia.bmkg?lang=EN). Meski demikian, layanan informasi tersebut menyediakan informasi cuaca secara global, nasional atau untuk lingkup wilayah dengan cakupan yang luas. Hal ini tentu saja belum memenuhi kebutuhan untuk memperoleh informasi cuaca untuk lingkup wilayah lokal tertentu, tempat di mana aktivitas yang terpengaruh oleh perubahan cuaca tersebut dilakukan.

Seiring dengan perkembangan terkini di bidang elektronika dan telekomunikasi, pengukuran parameter-parameter cuaca, seperti suhu (temperature), kelembaban (humidity), tekanan udara (barometric pressure), ketinggian (altitude) terhadap permukaan laut hingga intensitas cahaya (light intensity) dapat dilakukan secara mandiri pada skala lokal. Hasil pengukuran yang didapatkan selain disimpan untuk dianalisis lebih jauh juga dapat ditampilkan kepada khalayak luas, misalkan dalam bentuk halaman web melalui jaringan intranet maupun internet.

Iklim mikro atau iklim yang terdapat di wilayah lokal dengan cakupan yang lebih kecil menjadi sebuah objek penelitian untuk mendapatkan data darinya. Data tersebut diperoleh dari hasil pengukuran sensor BME280 untuk memperoleh nilai suhu, kelembaban dan tekanan udara, BH1750 untuk intensitas cahaya dan MQ-7 untuk kandungan karbon dioksida. Selain merekam data yang dihasilkan, mikropengendali PIC18F45K22 selanjutnya memutuskan untuk menutup tirai jendela, menyalakan lampu, menghidupkan pendingin udara (air conditioner) atau menyalakan kipas pembuangan (exhaust fan) dengan tampilan data melalui LCD [1]. Masih mengenai kondisi iklim mikro, sebuah penelitian mengukur dan merekam kondisi lingkungan di suatu lokasi dalam hutan menggunakan mikropengendali ESP8266 yang ditenagai oleh 4 buah baterai AA dengan sensor BME280 untuk mendapatkan data suhu dan kelembaban serta BH1750FVI untuk radiasi aktif sinar matahari. Data yang tersimpan di EEPROM selanjutnya diunduh dalam bentuk berkas CSV ke komputer sehingga tidak ada komponen untuk menampilkan data hasil pengukuran pada penelitian tersebut [2]. Data hasil pengukuran antara lain, suhu lingkungan, suhu objek, kelembaban relatif, tekanan udara dan intensitas cahaya juga dapat dikumpulkan dari berbagai simpul (node) perangkat ukur, yang masing-masingnya berupa mikropengendali ESP8266 dilengkapi sensor HTU21D, MLX90614, BME280, DHT22, DS18B20, MLX90614 dan BH1750FVI. Data dikirimkan dalam bentuk halaman web berformat JSON, lalu komputer Raspberry Pi memilah dan menyimpannya ke bentuk Comma-Separated Values (CSV) [3]. Pengukuran untuk mendapatkan data kondisi lingkungan dalam sebuah rumah kaca (greenhouse) telah dilakukan pada sebuah penelitian di Sri Lanka [4]. Sistem pengukuran menggunakan Arduino Mega dan sensor BME280 untuk memperoleh data suhu, tekanan udara dan kelembaban sedangkan BH1750FVI digunakan untuk mendapatkan data intensitas cahaya serta MH-Z14A untuk memperoleh kandungan karbondioksida. Data selanjutnya disimpan dalam database server dan ditampilkan berupa halaman web, sedangkan analisis data melalui algoritma pembelajaran mesin (machine learning) diterapkan untuk menentukan kapan kipas pembuangan dan penyemprot air (sprinkler) dijalankan.

Berdasarkan berbagai penelitian yang pernah dilakukan sebelumnya tersebut dapat ditelaah adanya dua poin penting. Pertama, data untuk parameter cuaca, seperti suhu, kelembaban dan tekanan udara diperoleh melalui sensor BME280 sedangkan intensitas cahaya didapatkan dari hasil pembacaan sensor BH1750FVI. Kedua, semua penelitian menekankan pada aspek pengukuran dan penyimpanan data, sedangkan tampilan data terbatas pada pilihan antara penggunaan LCD dan tampilan halaman web. Tujuan dari penelitian ini adalah melakukan rancang bangun untuk mendapatkan sebuah sistem penampil data cuaca lokal berupa web server yang menyediakan tiga macam tampilan data, yaitu LCD, komunikasi serial dan halaman web.

\section{KAJIAN PUSTAKA}

Berdasarkan pemaparan dari hasil-hasil penelitian sebelumnya tersebut maka dilakukan sebuah upaya rancang bangun untuk membentuk sebuah sistem penampil data cuaca dengan tiga mode tampilan. Ada pun bagian-bagian utama dari sistem tersebut adalah: 


\subsection{Arduino Uno R3}

Arduino (https://arduino.cc) adalah sebuah ekosistem pengembangan komputasi fisik (physical computing) open source yang berawal dari suatu proyek thesis Hernando Barragan dengan nama Wiring [5]. Dari sisi perangkat keras, terdapat bermacam-macam papan rangkaian Arduino yang tersedia, namun yang paling terkenal dan banyak digunakan adalah Arduno Uno R3. Penelitian ini menggunakan Arduino Uno R3 dengan mikropengendali ATmega328P versi SMD dan dimodifikasi dengan cip CH340 untuk komunikasi serial sebagai pengganti FTDI232RL. ATmega328P adalah mikropengendali 8 bit seri megaAVR dari Microchip yang memiliki 28 pin dengan 23 diantaranya untuk masukan dan keluaran, memori Flash 32KB, memori SRAM 2 KB, EEPROM 1 KB serta mampu berkomunikasi melalui protokol SPI, USART dan TWI [6].

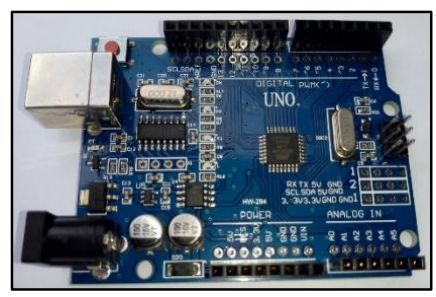

\subsection{Ethernet Shield}

Gambar 1. Arduino Uno R3

Dengan maksud untuk dapat menampilkan data cuaca secara terus-menerus dan dalam waktu-nyata (real time) dibutuhkan koneksi internet yang stabil pada web server. Oleh karena itu sistem arduino menggunakan blok tambahan (shield) ethernet yang mengakses internet melalui koneksi kabel UTP. Bagian utama dari shield ini adalah cip pengendali ethernet W5100 dari WIZnet yang mampu mengubah data dalam format serial ke ethernet dan mengirimkannya melalui protokol TCP/IP [7]. W5100 berkomunikasi dengan Arduino melalui protokol ISP sehingga pin 10 (SS), 11 (MOSI), 12 (MISO) dan 13 (SCK) tidak dapat digunakan untuk keperluan lain.

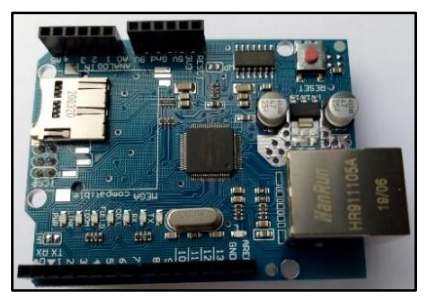

Gambar 2. Ethernet Shield

\subsection{BME280}

BME280 adalah sensor suhu, kelembaban dan tekanan udara dari Bosch Sensortec yang beroperasi dengan rentang tegangan $1,71-3,6$ Volt. Sensor ini mampu mengukur suhu dari $-40-85^{\circ} \mathrm{C}$, kelembaban relatif $0-100 \%$ dan tekanan udara $300-1100 \mathrm{hPa}$. Selain melalui protokol ISP, BME280 juga dapat berkomunikasi melalui protokol $\mathrm{I}^{2} \mathrm{C}$ dengan alamat piranti 0x76 atau 0x77 [8].

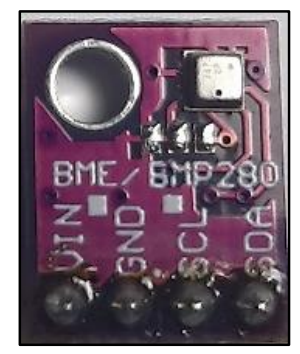

Gambar 3. Modul Sensor BME280 


\subsection{BH1750FVI}

BH1750FVI yang digunakan pada penelitian ini adalah sensor intensitas cahaya dari ROHM Semiconductor. Berbeda dengan sensor cahaya analog, sensor ini menghasilkan keluaran digital 16 bit, langsung dalam bentuk nilai lux (lx) dari 1 hingga 65535 dengan tegangan kerja 2,4-3,6 Volt. Antarmuka komunikasi yang digunakan adalah $\mathrm{I}^{2} \mathrm{C}$ dengan alamat piranti 0x23 atau 0x5C [9].

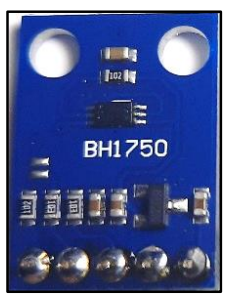

Gambar 4. Modul Sensor BH1750FVI

\subsection{RTC DS3231}

RTC atau Real Time Clock adalah cip yang berfungsi untuk menjalankan waktu dan tanggal pada sebuah rangkaian elektronik. Pada penelitian ini digunakan cip RTC DS3231 dari Maxim Integrated yang menyediakan fungsi jam (clock) dan kalendar, beroperasi pada tegangan 2,3 - 5,5 Volt, frekuensi osilator $32 \mathrm{KHz}$ dan berkomunikasi melalui protokol $\mathrm{I}^{2} \mathrm{C}$ pada alamat piranti 0x68 [10].

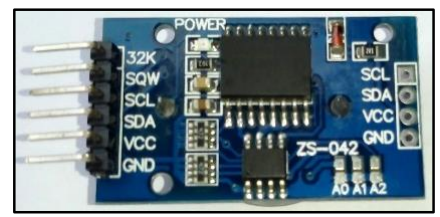

Gambar 5. Modul RTC DS3231

\section{6. $\mathrm{I}^{2} \mathrm{C}$}

Inter-Integrated Circuit atau $\mathrm{I}^{2} \mathrm{C}$ adalah sebuah protokol komunikasi yang dikembangkan oleh Philips Semiconductor yang banyak digunakan karena kesederhanaannya dalam proses pertukaran data. Protokol ini hanya menggunakan dua jalur, yaitu SCL untuk clock dan SDA untuk data, antara pihak pengendali atau master dan piranti yang dikendalikan atau slave. Jika mikropengendali berperan sebagai master maka semua piranti yang menggunakan protokol $\mathrm{I}^{2} \mathrm{C}$ cukup terhubung melalui jalur SDA dan SCL tersebut dan masing-masingnya dibedakan berdasarkan alamat pirantinya (device address) [11].

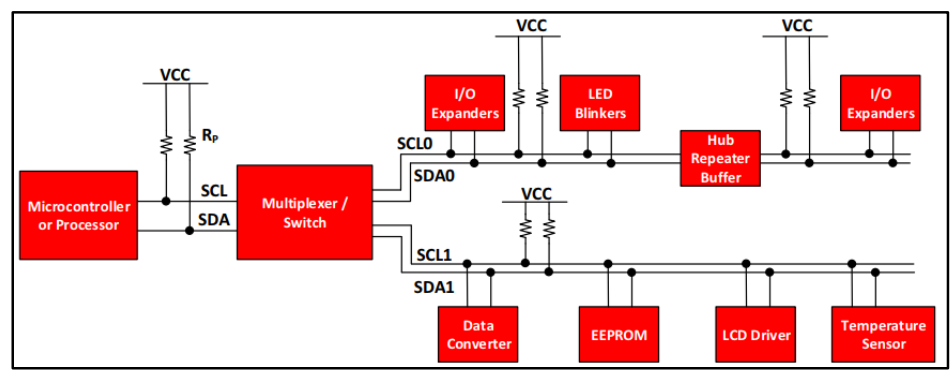

Gambar 6. Konfigurasi Master-Slave pada $\mathrm{I}^{2} \mathrm{C}[11]$

\section{METODE PENELITIAN}

Dalam pelaksanaan penelitian ini terdapat empat tahap yang dilakukan yaitu meliputi perancangan sistem, perancangan perangkat keras (hardware), perancangan perangkat lunak (software) dan pengujian.

\subsection{Perancangan Sistem}

Sistem yang dirancang memiliki bagian-bagian dan koneksi seperti dalam gambar 7 berikut ini: 


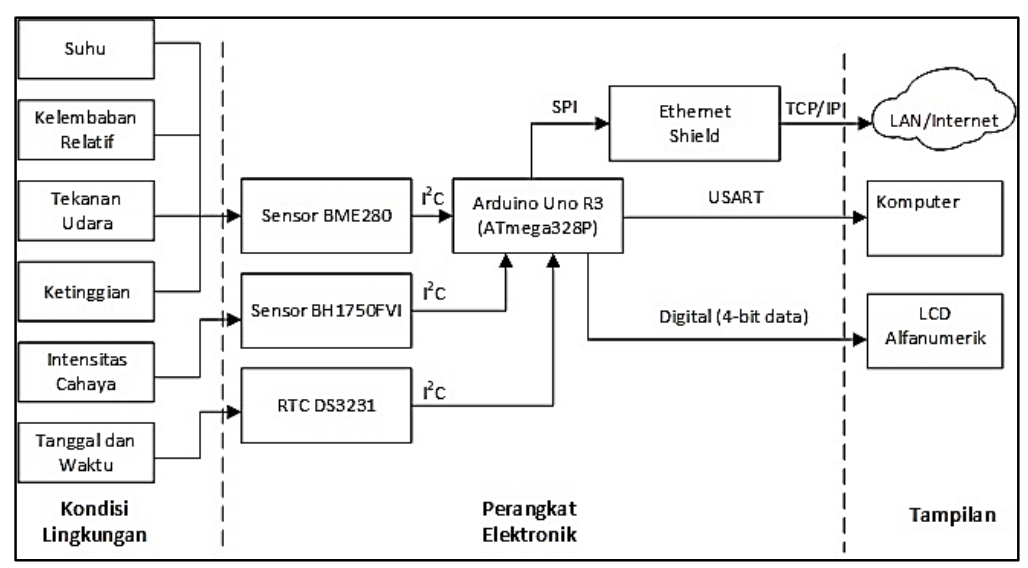

Gambar 7. Blok Diagram Sistem

Secara garis besar, sistem terdiri dari tiga bagian, yaitu kondisi lingkungan yang diukur atau diambil datanya, perangkat elektronik yang akan menjalankan proses pengukuran, pemrosesan dan pengiriman data dan bagian tampilan yang memunculkan data hasil pengukuran sensor dan nilai dari RTC. Kondisi lingkungan yang diukur oleh sensor BME280 meliputi suhu, kelembaban relatif, tekanan udara dan ketinggian (terhadap permukaan laut). Sedangkan intensitas cahaya diukur oleh sensor BH1750FVI. RTC sendiri berfungsi untuk menghasilkan timestamp yaitu waktu dan tanggal kapan data hasil pengukuran tersebut diambil.

Data pengukuran dan nilai RTC itu selanjutnya dikirimkan ke Arduino Uno R3 melalui protokol $\mathrm{I}^{2} \mathrm{C}$. Setelah diproses, mikropengendali mengirimkannya ke Ethernet Shield via antarmuka SPI yang kemudian ditampilkan dalam bentuk web server di sebuah LAN atau situs internet melalui protokol TCP/IP. Data juga dikirimkan ke dua perangkat penampil lainnya, yaitu ke sebuah komputer dengan komunikasi serial (USART) dan menuju sebuah LCD alfanumerik dengan bentuk data digital 4-bit.

\subsection{Perancangan Perangkat Keras (Hardware)}

Bagian utama dari rangkaian sistem penampil data cuaca ini adalah Arduino Uno R3 dengan mikropengendali ATmega328P di dalamnya. Arduino dihubungkan dengan sensor BME280, BH1750FVI dan RTC DS3231 sebagai masukan sedangkan bertindak sebagai keluaran adalah ethernet shield, komputer lain yang terhubung melalui komunikasi serial dan sebuah LCD alfanumerik. Koneksi pin pada Arduino (dan ATmega328P di dalamnya) untuk berbagai perangkat luar tersebut adalah sebagaimana dipaparkan dalam tabel 1 berikut ini.

Tabel 1. Koneksi Pin pada Arduino

\begin{tabular}{|c|c|c|c|}
\hline \multicolumn{2}{|c|}{ Pin } & \multirow{2}{*}{$\begin{array}{c}\text { Koneksi/ } \\
\text { Fungsi }\end{array}$} & \multirow{2}{*}{ Keterangan } \\
\hline Arduino & ATmega328P & & \\
\hline $\mathrm{A} 4$ & PC4 & SDA & Pin SDA di BME280, BH1750FVI dan DS3231 \\
\hline A5 & PC5 & SCL & Pin SCL di BME280, BH1750FVI dan DS3231 \\
\hline 0 & PD0 & RX & Pin Receive untuk USART (ke komputer) \\
\hline 1 & PD1 & TX & Pin Transmit untuk USART (ke komputer) \\
\hline 2 & PD2 & $\mathrm{RS}$ & Pin Read Strobe (RS) pada LCD Alfanumerik \\
\hline 3 & PD3 & EN & Pin Enable (EN) pada LCD Alfanumerik \\
\hline 4 & PD4 & D4 & Pin D4 pada LCD Alfanumerik \\
\hline 5 & PD5 & D5 & Pin D5 pada LCD Alfanumerik \\
\hline 6 & PD6 & D6 & Pin D6 pada LCD Alfanumerik \\
\hline 7 & PD7 & D7 & Pin D7 pada LCD Alfanumerik \\
\hline 10 & PB2 & SS & Pin SS pada Ethernet Shield \\
\hline 11 & PB3 & MOSI & Pin MOSI pada Ethernet Shield \\
\hline 12 & PB4 & MISO & Pin MISO pada Ethernet Shield \\
\hline 13 & PB5 & SCK & Pin SCK pada Ethernet Shield \\
\hline
\end{tabular}

Perangkat sensor dan RTC semuanya terhubung melalui protokol $\mathrm{I}^{2} \mathrm{C}$, bertindak sebagai slave dengan alamat piranti (device address) yang diatur seperti dalam tabel 2. Karena ada cukup banyak perangkat yang terhubung ke Arduino maka sebuah breadboard power supply dengan baterai $9 \mathrm{~V}$ ditambahkan ke rangkaian untuk memberikan tegangan kerja 3,3 V ke sensor dan RTC sedangkan 
tegangan 5 V diberikan ke LCD alfanumerik. Adapun bagian ground dihubungkan ke pin GND pada Arduino, selain juga ke perangkat-perangkat tersebut.

Tabel 2. Alamat Perangkat untuk Protokol ${ }^{2} \mathrm{C}$

\begin{tabular}{cc}
\hline Perangkat & Device Address \\
\hline BME280 & $0 \times 76$ \\
BH1750FVI & $0 \times 23$ \\
DS3231 & $0 \times 68$ \\
\hline
\end{tabular}

\subsection{Perancangan Perangkat Lunak (Software)}

Program yang berjalan di Arduino Uno tersebut ditulis dengan menggunakan bahasa pemrograman Arduino, yang memiliki dialek seperti bahasa C, melalui Arduino IDE versi 1.8.13. Cara kerja dari program adalah seperti digambarkan dalam diagram alir pada gambar 8. Secara garis besar, program tersebut tersusun dari dua buah sub program, yaitu inisialisasi yang berisi instruksi-instruksi untuk dijalankan sekali saja di kesempatan awal dan perulangan yang akan mengeksekusi perintah terusmenerus dari saat perangkat dinyalakan hingga dimatikan.

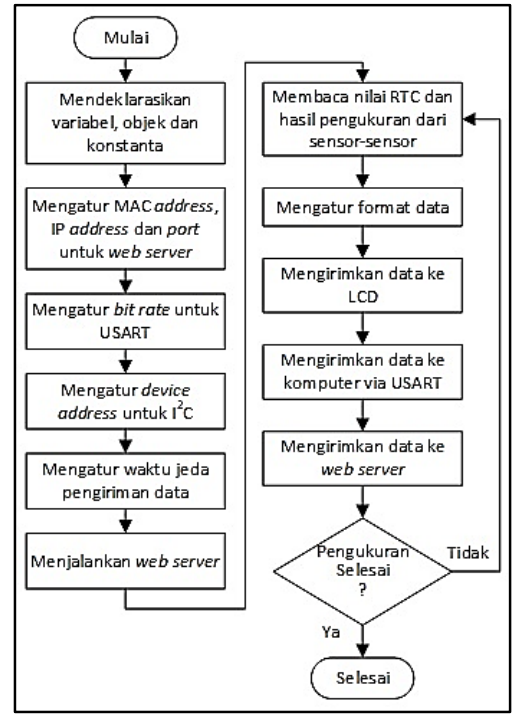

Gambar 8. Diagram Alir Program

Saat pertama kali dijalankan, program memasuki tahap inisialisasi lalu berturut-turut mendeklarasikan semua variabel, objek dan konstanta, melakukan pengaturan awal untuk web server, komunikasi serial (USART), $\mathrm{I}^{2} \mathrm{C}$, waktu jeda transmisi data dan ditutup dengan mengaktifkan web server. Selanjutnya bagian utama dari program tersebut adalah berupa perulangan instruksi-instruksi untuk membaca data pengukuran dan nilai RTC, mengatur format data dan mengirimkannya ke tiga tujuan, yaitu web server, komputer lain dan LCD alfanumerik.

\subsection{Pengujian}

Pengujian yang dilakukan untuk penelitian ini terbagi menjadi 2 macam, yaitu pengujian pengukuran dan tampilan data. Pengujian pengukuran meliputi hasil-hasil pembacaan sensor suhu BME280 dan BH1750FVI. Sedangkan tampilan data yang diamati adalah sebagaimana yang muncul pada web server, komunikasi serial dan LCD alfanumerik.

\section{HASIL DAN PEMBAHASAN}

Metode pengujian, hasil-hasil yang diperoleh beserta pembahasannya adalah sebagaimana dijelaskan berikut ini:

\subsection{Pengujian Pengukuran}

Pengujian untuk pengukuran sensor BME280 dan BH1750FVI dilakukan pada tanggal 16 Agustus 2020 selama satu jam dari pukul 08.31 hingga 09.30 WIB di sebuah ruangan (indoor) dengan 
ventilasi terbuka di daerah Banyumanik, Semarang. Data suhu $\left({ }^{\circ} \mathrm{C}\right)$, kelembaban $(\%)$, tekanan udara $(\mathrm{hPa})$, ketinggian $(\mathrm{m})$ dan intensitas cahaya (lx) dicatat setiap 1 menit sekali. Khusus untuk tiga parameter yang disebutkan pertama tersebut hasilnya dibandingkan langsung dengan yang tertampil di situs The Weather Channel (https://weather.com/) untuk waktu dan lokasi pengukuran (Banyumanik, Semarang) yang sama. Ada pun situs tersebut dipilih karena selain digunakan oleh mesin pencari Google, juga mampu memberikan hasil yang akurat untuk suatu kawasan tertentu. Seperti diperlihatkan dalam gambar 9, nilai untuk suhu didapatkan dari pembacaan saat itu (now) sedangkan kelembaban (humidity) dan tekanan udara (pressure) ditunjukkan di bagian b dan c.

Sedangkan untuk hasil pengukuran ketinggian hasilnya dibandingkan dengan informasi resmi dari Pemerintah Kota Semarang yang menyebutkan bahwa Kecamatan Banyumanik terletak di ketinggian $\pm 250 \mathrm{~m}$ dari permukaan laut [12]. Dari hasil perbandingan keempat parameter tersebut maka diperoleh nilai kesalahan (error) dalam persentase berdasarkan nilai reratanya sesuai rumusan berikut ini:

$$
\delta=\left|\frac{v_{A}-v_{E}}{v_{E}}\right| \times 100 \%
$$

Dengan $\mathrm{v}_{\mathrm{A}}$ adalah nilai pengukuran yang diperoleh dari pembacaan sensor sedangkan $\mathrm{v}_{\mathrm{E}}$ adalah nilai referensi yang diperoleh dari web. Sedangkan hasil ukur intensitas cahaya cukup dilakukan analisis sederhana untuk menentukan nilai terendah, tertinggi dan rata-ratanya.

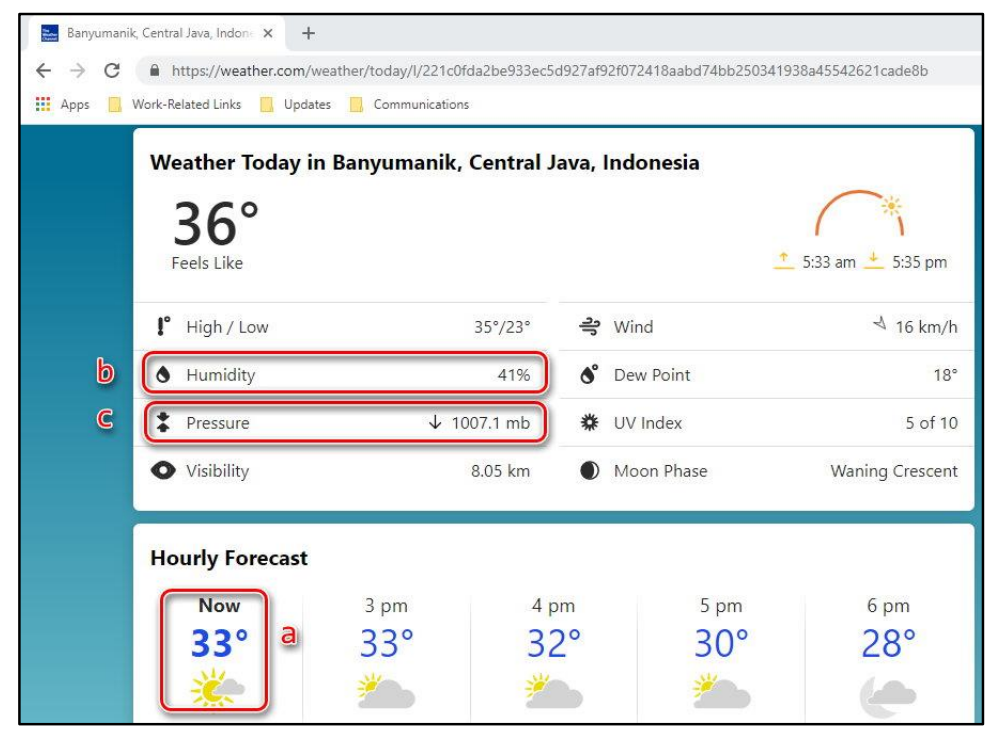

Gambar 9. Nilai Suhu (a), Kelembaban (b) dan Tekanan (c) dari Web (https://weather.com)

Berdasarkan hasil-hasil yang diperoleh untuk kelima parameter tersebut, kemudian setelah dilakukan pengolahan data terhadapnya didapatkan hasil sebagaimana tabel 3 di bawah ini:

Tabel 3. Perbandingan antara Hasil Pengukuran dengan Data Referensi

\begin{tabular}{ccccccc}
\hline Nilai & Data & Suhu $^{* 1}$ & $\begin{array}{c}\text { Kelembaban }^{* 1} \\
\text { Relatif }\end{array}$ & $\begin{array}{c}\text { Tekanan }^{* 1} \\
\text { Udara }\end{array}$ & Ketinggian $^{* 2}$ & $\begin{array}{c}\text { Intensitas }^{* 3} \\
\text { Cahaya }\end{array}$ \\
\hline \multirow{2}{*}{ Terendah } & Referensi & $28^{\circ} \mathrm{C}$ & $60 \%$ & $1011,2 \mathrm{hPa}$ & $250 \mathrm{~m}$ & $58,051 \mathrm{x}$ \\
& Pengukuran & $25,93^{\circ} \mathrm{C}$ & $70,58 \%$ & $1008,8 \mathrm{hPa}$ & $239,89 \mathrm{~m}$ & \\
Tertinggi & Referensi & $30^{\circ} \mathrm{C}$ & $71 \%$ & $1011,2 \mathrm{hPa}$ & $250 \mathrm{~m}$ & $100,631 \mathrm{x}$ \\
& Pengukuran & $26,83^{\circ} \mathrm{C}$ & $74,06 \%$ & $1008,9 \mathrm{hPa}$ & $240,53 \mathrm{~m}$ & \\
Rerata & Referensi & $28,72^{\circ} \mathrm{C}$ & $65 \%$ & $1011,2 \mathrm{hPa}$ & $250 \mathrm{~m}$ & $83,85 \mathrm{~lx}$ \\
& Pengukuran & $26,57^{\circ} \mathrm{C}$ & $71,83 \%$ & $1008,8 \mathrm{hPa}$ & $240,35 \mathrm{~m}$ & \\
Error $^{* 4}$ & & $\mathbf{7 , 4 2} \%$ & $\mathbf{1 0 , 9 5 \%}$ & $\mathbf{0 , 2} \%$ & $\mathbf{3 , 8 6 \%}$ & \\
\hline
\end{tabular}

Keterangan:

*1 Suhu, kelembaban relatif dan tekanan udara menggunakan data referensi dari The Weather Channel (https://weather.com/) untuk waktu (16 Agustus 2020, 08.31-09.30 WIB) dan lokasi pengambilan data yang sama (Banyumanik, Semarang, Indonesia) untuk pembanding. *2 Ketinggian menggunakan data referensi dari situs Pemerintah Kota Semarang yang menyatakan bahwa Kecamatan Banyumanik terletak $\pm 250 \mathrm{~m}$ di atas permukaan laut [12]. Data pengukuran didapatkan pada waktu dan lokasi yang sama seperti keterangan sebelumnya. 
*3 Pengukuran Intensitas Cahaya hanya untuk mendapatkan nilai terendah, tertinggi dan rerata tanpa menbandingkan dengan nilai re ferensi sehubungan pengukuran dilakukan di dalam ruangan tertutup yang berbeda kondisi pencahayaannya dengan data cuaca di luar ruangan. Pengukuran juga dilakukan pada kurun waktu yang sama dengan parameter lainnya.

*4 Penghitungan persentase error dilakukan untuk nilai rerata dari hasil pengukuran dan data referensi untuk semua parameter, kecuali intensitas cahaya.

Rekapitulasi tersebut didapatkan dari 60 nilai untuk masing-masing parameter, yang dibandingkan juga terhadap 60 nilai dari situs The Weather Channel bagi parameter suhu, kelembaban relatif dan tekanan udara. Suhu dan kelembaban udara menunjukkan error yang cukup besar, ini karena informasi yang diperoleh dari situs berlaku untuk wilayah Banyumanik secara umum, sedangkan perangkat sensor mengukur kondisi iklim mikro secara lokal di sebuah ruangan. Nilai-nilai untuk tekanan udara dan ketinggian menunjukkan hasil yang konstan dengan error yang relatif lebih kecil. Sedangkan nilai intensitas cahaya memperlihatkan sebuah hasil yang logis yaitu nilai terendah sebesar 58,05 lx terjadi di awal pengukuran sedangkan nilai tertinggi 100,63 lx didapatkan di akhir pengukuran. Ini menunjukkan kondisi pencahayaan yang semakin terang saat waktu beranjak semakin siang.

\subsection{Tampilan Data}

Data yang sudah diproses oleh Arduino selanjutnya ditampilkan melalui tiga media yaitu web server, komputer lain dan LCD alfanumerik. Pada proses pengujian untuk web server, data hasil ukur dan nilai RTC dimunculkan dalam sebuah halaman HTML dengan tambahan beberapa kode CSS untuk mengatur format tampilan. Untuk memuat data terbaru, halaman tersebut melakukan refresh tiap 5 detik sekali. Pengujian ini dilakukan di jaringan lokal (LAN) dengan server berada di alamat IP 192.168.1.160 dan port 80. Tampilan yang dihasilkan adalah seperti pada gambar di bawah ini.

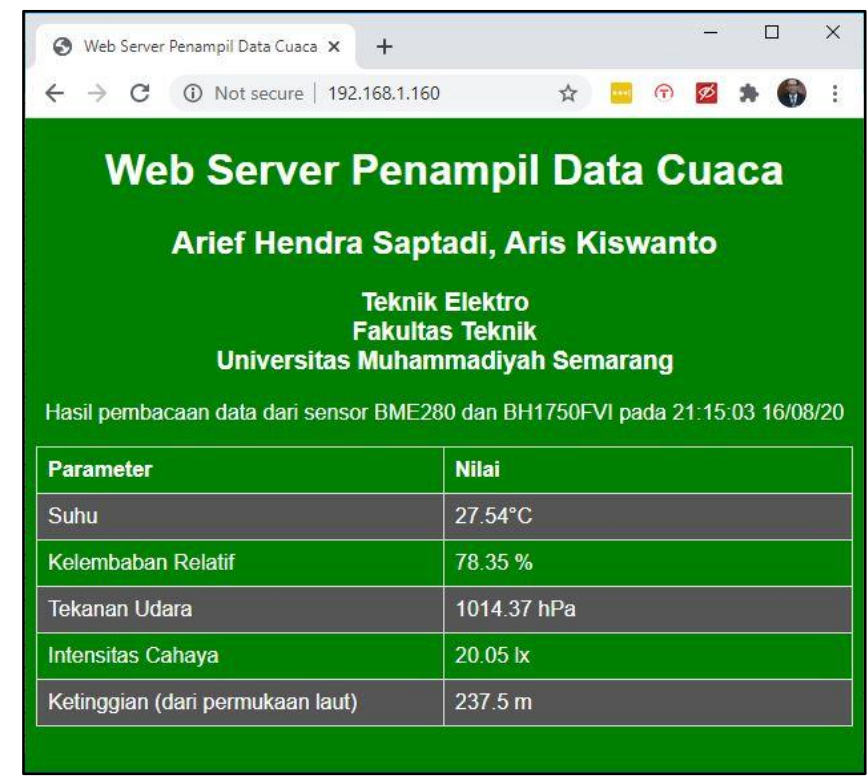

Gambar 10. Tampilan Data dalam Halaman Web

Hasil pengukuran dan nilai dari RTC yang dikirimkan ke komputer lain melalui komunikasi serial ditampilkan dengan menggunakan fitur Serial Monitor yang terdapat di aplikasi Arduino IDE. Tampilan yang muncul adalah seperti dalam gambar 11. Data berbentuk Comma-Separated Values (CSV) yang memiliki format:

[Suhu],[Kelembaban],[Tekanan],[Ketinggian],[Cahaya],[Jam:Menit:Detik],[Tanggal/Bulan/Tahun] 


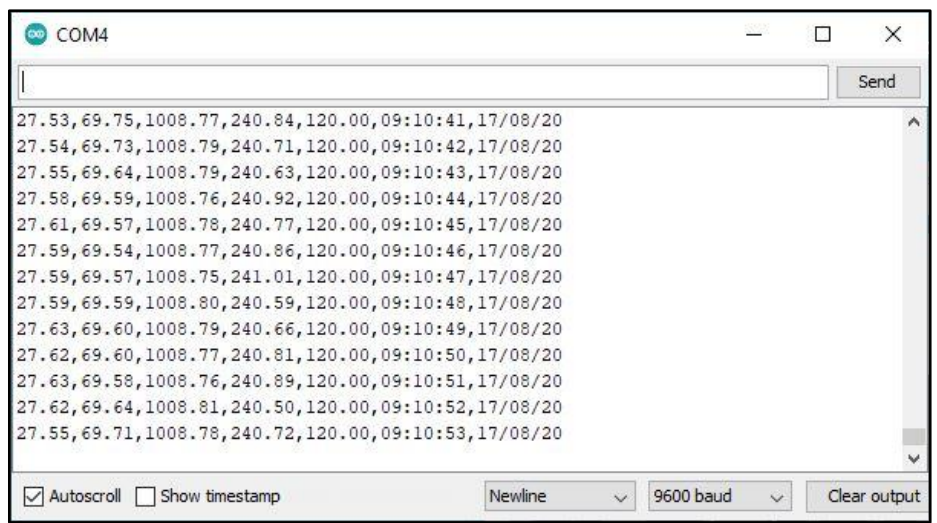

\section{Gambar 11. Tampilan Data pada Komunikasi Serial}

Data dikirimkan ke LCD setiap detik, namun karena keterbatasan jumlah kolom dan baris untuk menampilkannya (yaitu 16 kolom dan 2 baris), maka tampilan di LCD dibagi menjadi dua bentuk. Bentuk pertama terdiri dari nilai intensitas cahaya, ketinggian, jam dan tanggal. Bentuk ini ditampilkan selama 5 detik. Sedangkan bentuk kedua terdiri dari nilai suhu, kelembaban dan tekanan udara. Tampilan tersebut muncul selama 5 detik untuk selanjutnya beralih ke bentuk pertama dan demikian seterusnya.

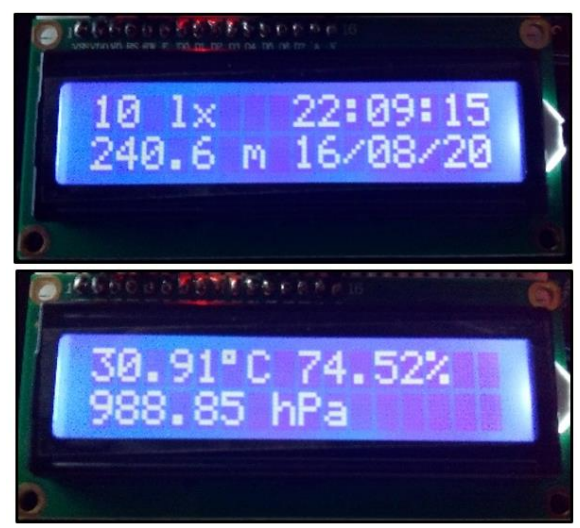

Gambar 12. Tampilan Data pada LCD Alfanumerik

Sesuai bentuk tampilan dalam tiga mode tersebut juga dapat diamati bahwa informasi mengenai tanggal dan jam telah dapat ditampilkan dengan baik. Oleh karenanya ini merupakan sebuah indikasi bahwa RTC DS3231 telah bekerja seperti dalam rancangan.

\section{KESIMPULAN}

Berdasarkan rancang bangun yang sudah dilakukan dan hasil-hasil pengujian yang didapatkan maka dapat disimpulkan beberapa hal seperti berikut ini:

1. Nilai rata-rata untuk suhu dan kelembaban, masing-masing sebesar $28,72^{\circ} \mathrm{C}$ dan $65 \%$ dengan error sebesar 7,42\% dan 10,95\%, yang mana ini cukup besar karena nilai referensi dari situs berdasarkan suatu wilayah secara umum, sedangkan sensor mengukur kondisi iklim lokal.

2. Nilai rata-rata untuk tekanan udara dan ketinggian relatif konstan, yaitu masing-masing sebesar $1011,2 \mathrm{hPa}$ dan 240,35 m dengan error yang lebih kecil yaitu $0,2 \%$ dan $3,86 \%$.

3. Nilai intensitas cahaya berada dalam rentang 58,05 - 100,63 lx dengan rerata 83,85 lx yang menggambarkan perubahan pencahayaan seiring dengan waktu yang semakin siang.

4. Sistem yang dirancang sudah dapat menampilkan data hasil pengukuran dan nilai RTC ke web server, komputer maupun LCD alfanumerik.

5. Informasi mengenai waktu dan tanggal telah dapat dimunculkan dalam tiga mode tampilan dengan baik sehingga ini mengindikasikan RTC DS3231 sudah dapat berfungsi sesuai rancangan awal. 


\section{REFERENSI}

[1] M. Djordjević, B. Jovičić, S. Marković, V. Paunović, and D. Danković, “A smart data logger system based on sensor and Internet of Things technology as part of smart faculty, "Journal of Ambient Intelligence and Smart Environments, vol. 12, no. 4, pp. 359-373, 2020, doi: 10.3233/AIS-200569.

[2] J. G. Mickley, T. E. Moore, C. D. Schlichting, A. DeRobertis, E. N. Pfisterer, and Robert Bagchi, "Measuring microenvironments for global change: DIY environmental microcontroller units (EMUs)," Methods in Ecology and Evolution, vol. 10, issue 4, pp. 578-584, 2019, doi: 10.1111/2041-210X.13128.

[3] I. Stoev and V. Mutkov, "Microclimatic data collection multisensor system for design of energy model in residential buildings," 2018 20th International Symposium on Electrical Apparatus and Technologies (SIELA), Bourgas, 2018, pp. 1-3, doi: 10.1109/SIELA.2018.8447124.

[4] Y. P. Jayasuriya, C. S. Elvitigala, K. Warnakulasooriya, and B. H. Sudantha, "Low Cost and IoT based Greenhouse with Climate Monitoring and Controlling System for Tropical Countries," 2018 International Conference on System Science and Engineering (ICSSE), New Taipei, 2018, pp. 1-6, doi: 10.1109/ICSSE.2018.8519997.

[5] M. Banzi and M. Shiloh, 2015. Getting Started With Arduino. 3rd ed. Sebastopol: Maker Media, p.2.

[6] Microchip Technology Incorporated, “ATmega48A/PA/88A/PA/168A/PA/328/P," megaAVR® datasheet, 2018 [Revision A - October 2018].

[7] Wiznet, "W5100 Datasheet," W5100 datasheet, 2019 [Version 1.2.8 - May 20 th 2019].

[8] Bosch Sensortec GmBH, "BME280 Combined humidity and pressure sensor," BME280 datasheet, 2018 [Revision 1.6 - September 2018].

[9] ROHM Semiconductor, "Ambient Light Sensor IC Series Digital 16bit Serial Output Type Ambient Light Sensor IC," BH1750FVI datasheet, 2011 [Revised November, 2011].

[10] Maxim Integrated, "DS3231 Extremely Accurate $I^{2}$ C-Integrated RTC/TCXO/Crystal," DS3231 datasheet, 2015 [ Revision 10 - March 2015].

[11] J. Valdez, J. Becker, "Understanding the I²C Bus," Application Report, Texas Instruments, June 2015.

[12] Pemerintah Kota Semarang. (2020). Kecamatan Banyumanik, Geografis dan Penduduk [Online]. Address: https://kecbanyumanik.semarangkota.go.id/geografis-dan-penduduk. Accessed: August $16^{\text {th }}$, 2020.

\section{BIOGRAFI PENULIS}

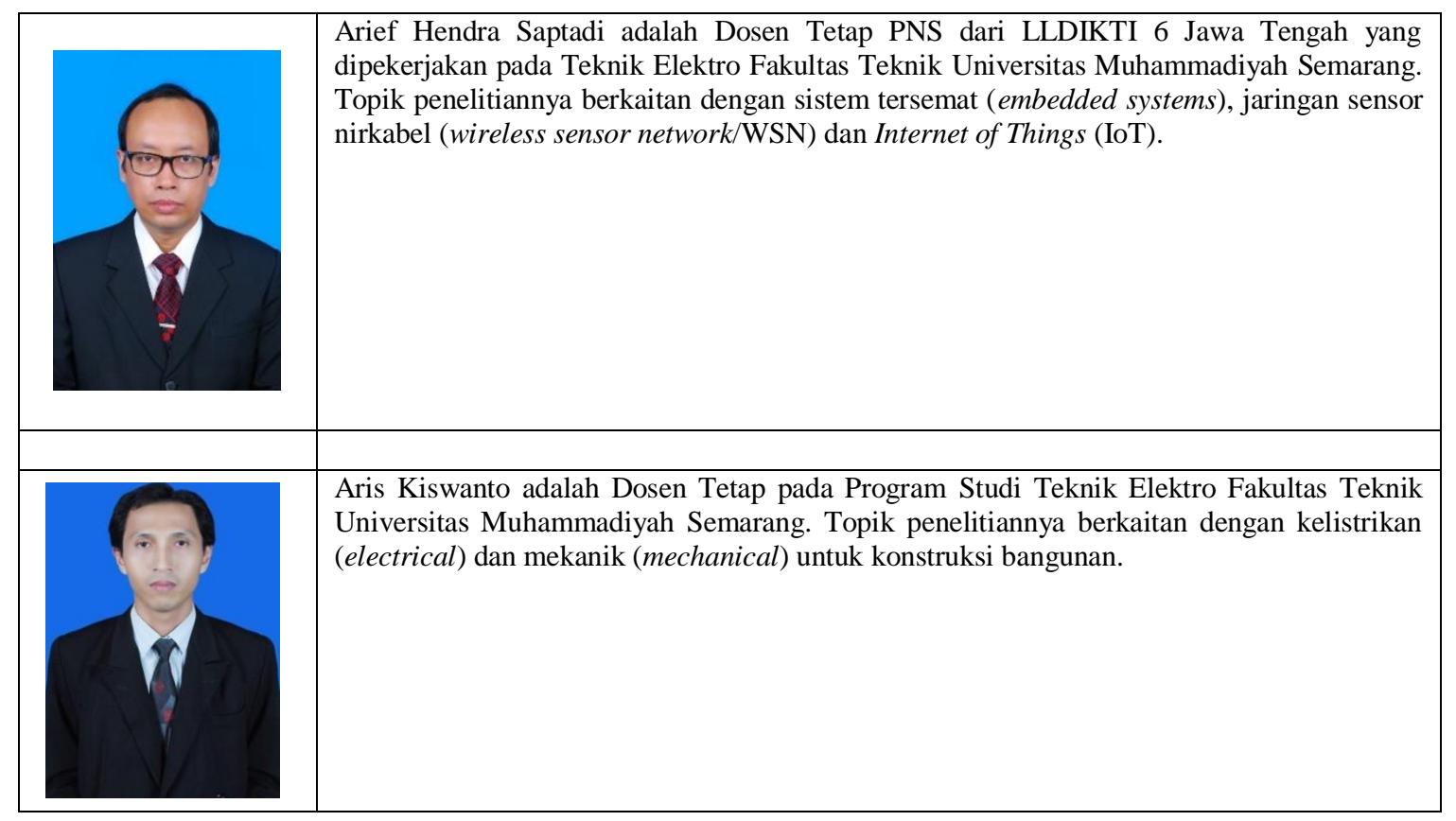

